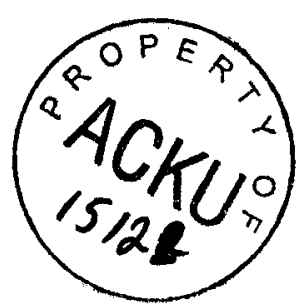

UNESCO Press Release No. 2007-21

\title{
Return of 1,300 artefacts to National Museum of Afghanistan, under aegis of UNESCO
}

Paris, 12 March - Some 1,300 Afghan ethnographic and archaeological objects, preserved since 1999 at the Afghanistan Museum-in-Exile (Bubendorf, Switzerland) under the aegis of UNESCO, will be handed over to the National Museum in Kabul on 16 March. Some of the most exceptional pieces will be presented at a press conference organized in the National Museum of Afghanistan on 17 March, at 10 a.m.

The operation, organized by the Afghan Ministry of Information and Culture, is financed by Switzerland's National Commission to UNESCO, the Swiss Federal Department of Foreign Affairs and the German Ministry of Defense, which is responsible for the transport.

"Repatriating this collection that we have preserved for six years in the Afghanistan Museum-in-Exile in Bubendorf, Switzerland, means giving back to Afghanistan a part of its memory. The country needs this to reconstruct its identity," said Koïchiro Matsuura, Director-General of UNESCO.

According to the terms of an agreement with UNESCO, the Afghanistan Museum-in-Exile received 1,300 pieces from private donors. Volunteer specialists made a complete inventory of the artefacts. In order not to incite the illicit export of works of art from Afghanistan, the contract stipulated that no objects would be bought. The museum, which just closed, was established by the Foundation Bibliotheca Afghanica, a Swiss foundation created in 1975 as a centre of documentation on Afghanistan. Financed by private donors, the Swiss Federal Government and the Cantonal Government of BaselLandschaft, the Museum-in-Exile project cost about US\$1 million.

UNESCO also contributed to the reconstruction of the National Museum of Afghanistan, which is now ready to house the collection. Founded in 1930, the museum was looted and deliberately vandalized under the Taliban regime. Since the fall of that regime in 2001, UNESCO has been organizing and coordinating national and international efforts to rehabilitate the establishment. As a result of these initiatives, the National Museum was able to open to the public again in October 2004.

Since 2002, the building has been entirely restored and equipped, thanks to funds given notably by Italy, the United States, Greece and Japan, with the participation of the Society for the Preservation of A fghanistan's Cultural Heritage (SPACH), the National Geographic Society, the British Museum, the Musée Guimet in Paris and other donors.

Meanwhile, UNESCO launched a comprehensive training programme in inventory, conservation, exhibiting collections and publications. The Organization further contributed to the completion of an inventory of nearly $75 \%$ of the museum's holdings and the construction of a database.

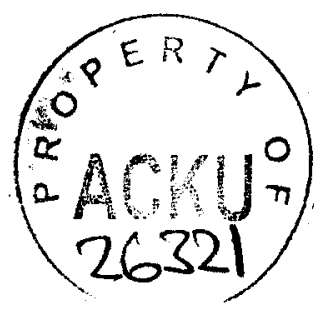




\section{UNESCOPRESS/No.2006-21 - 2}

Last October, UNESCO published an illustrated inventory of pieces found in the national museum's showcases and reserves until 1985 (Francine Tissot, Catalogue of The National Museum of Afghanistan, 1931-1985, UNESCO Publishing, 2006). An educational and practical tool, it conserves the memory of now-scattered collections and can help in their reconstitution.

UNESCO's action on behalf of Afghanistan's cultural heritage goes back to the 1970s and the international campaign for the safeguarding of the city of Herat. Since then, the Organization has notably produced an inventory of the Bagram ivories, constituting the only testimony to the entire collection of these objects, most of which have now disappeared. Currently UNESCO is pursuing the effort to consolidate the cliffs of Bamiyan, the fifth Herat minaret and the minaret of Jam, the first Afghan site to be inscribed on the World Heritage List (in 2002).

For accreditation, journalistes should contact:

UNESCO's Office in Kaboul:

Masanori Nagaoka, Tel.+93-799-635-254,masanori.nagaoka@undp.org

Contact:

Jasmina Sopova

Press Relations Section, Tel.+33(0)1456817 17,j.sopova@unesco.org 


\section{Introduction of UNESCO Culture Section:}

The UNESCO culture programme works in cooperation with the government of Afghanistan to safeguard and promote the tangible and intangible cultural heritage, cultural diversity and human rights in Afghanistan. Our activities in Afghanistan re-affirm UNESCO's mission as stated in the Preamble to its Constitution that aims to promote peace through the intellectual and moral solidarity of humankind. To this end, we continue to assist the Afghan authorities in delivering projects to safeguard Afghanistan's tangible and intangible cultural heritage and to promote public awareness amongst the Afghan people of the immense value of that heritage and preserving it for future generations. We also seek to promote crosscultural awareness and dialogue concerning Afghanistan's heritage as a valuable component of the world's natural and cultural heritage that enriches us all through an understanding of its contribution to history, art and science.

Since 2002, UNESCO has been coordinating/implementing projects in the provinces of Kabul, Bamiyan, Ghazni, Herat, Ghor, Balkh, Sari Pul, Jawzjan and Faryab in close cooperation and partnership with the Afghan authorities and a number of other partners, funded by international donors. UNESCO assists the Government of Afghanistan in their endeavors to inventory, conserve and rehabilitate monuments, sites and other cultural property, while attempting to tackle the problem of illicit traffic in antiquities. Attention has been focused on the four principal departments of the Ministry of Information and Culture (Museums, Historical Monuments, National Archives and the Institute of Archaeology) responsible for inventory, conservation and restoration of cultural heritage. Projects include significant vocational training and capacity-building components while also achieving measurable inventory and conservation results, in compliance with the strategic coordination of the Afghanistan Compact and the Afghanistan National Development Strategy through the Consultative Group mechanism. UNESCO continues to support the Ministry in order to enhance the ability of all four Departments to safeguard, preserve and manage cultural heritage resources in Afghanistan.

The main activities are:

- Safeguarding Bamiyan World Heritage Site

- Emergency Consolidation and Restoration of the Monuments of Herat and Jam

- Rehabilitation of the Museums of Ghazni

- Archaeological Surveys in the regions of Bamiyan, Sar -i- Pul, Jawzjan and Faryab

- Conservation of Tepe Narenj, Kabul

- Documentation of Cultural Monuments in Kabul Region

- International Coordination Committee for Safeguarding Afghanistan's Cultural Heritage

- Rehabilitation of the National Museum of Afghanistan: Structural Repairs to the Building and Grounds, Documentation, Conservation and Exhibition of its Collections

- Expert Working Group Meeting for the Site of Bamiyan

- Enhancement of Intercultural and Inter-religious dialogue through Silk Roads Restoration of Haji Piyada

- Inventory and Documentation of Afghanistan's Traditional Music for Public Awareness and Sustainable Development

UNESCO would like to take this opportunity to thank all of these generous donors and partners for their invaluable contributions.

Contact : UNESCO's Office in Kabul Masanori Nagaoka, Tel. 070-269-012, masanori.nagaoka@undp.org

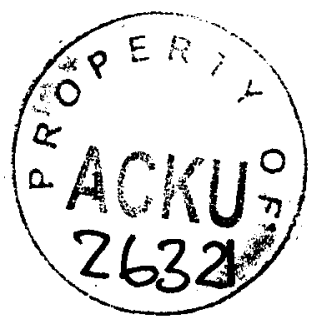

